\title{
Radiation-induced tumours of meninges. Report on eight cases and review of the literature
}

\section{Popromienne guzy opon mózgowo-rdzeniowych. Opis ośmiu przypadków i przeglqad piśmiennictwa}

\author{
Przemysław Kunert', Ewa Matyja ${ }^{2}$, Marek Prokopienko', Andrzej Marchel' \\ IDepartment of Neurosurgery, Medical University of Warsaw \\ 2Department of Experimental and Clinical Neuropathology, Medical Research Centre, Polish Academy of Sciences, Warsaw
}

Neurologia i Neurochirurgia Polska 2012; 46, 6: 542-552

DOI: 10.5114/ninp.2012.32099

\begin{abstract}
Background and purpose: Despite their rarity, post-radiation meningeal tumours seem to be a growing problem due to the increasing application of radiation therapy. The aim of the study was to ascertain the specific features of these tumours. Material and methods: Among 433 intracranial meningeal tumours treated from 2000 to 2008 , eight cases (2\%) have been presumed to be associated with high-dose therapeutic radiation for previous neoplasm of the head (7) or neck (1). On average, tumours were diagnosed 24 years after irradiation. All patients had a solitary meningeal tumour, but two of them also developed other neoplasms in the irradiated area. Results: All tumours were microsurgically removed. The postoperative course was uncomplicated in two cases only. In the remaining 6 (75\%), complications included liquorrhoea (2), brain oedema (1), venous thrombosis (1), bleeding into the tumour bed (1) and focal deficit due to manipulation (3). Most tumours (5) were WHO grade I meningiomas. These benign meningiomas exhibited some peculiar histological features, including focal increase of cellularity, focal enhancement of proliferation index, pleomorphism of nuclei, occasional mitotic figures and, in one case, evidence of brain invasion. One meningioma was assigned to WHO grade II, one to WHO grade III and one appeared to be meningeal fibrosarcoma. The event-free survival and overall survival rate at 4.4 years of follow-up were $63 \%$ and $75 \%$, respectively.
\end{abstract}

\section{Streszczenie}

Wstęp i cel pracy: Popromienne guzy opon mózgowo-rdzeniowych - mimo że stwierdzane rzadko - wydają się narastającym problemem ze względu na szerokie zastosowanie radioterapii. Celem pracy jest charakterystyka kliniczna i histopatologiczna tych guzów.

Materiał i metody: Spośród 433 śródczaszkowych guzów oponowych operowanych w latach 2000-2008, w 8 przypadkach (2\%) stwierdzono związek pomiędzy powstaniem guza a przebytą radioterapią z powodu nowotworów głowy (7) i szyi (1). Guzy popromienne były rozpoznawane średnio po 24 latach od napromieniania. U wszystkich pacjentów wystąpiły pojedyncze guzy opon, ale u 2 dodatkowo pojawiły się inne nowotwory w obszarze napromienianym.

Wyniki: Wszystkie guzy były leczone mikrochirurgicznie. Przebieg pooperacyjny bez powikłań obserwowano tylko u 2 pacjentów. U pozostałych 6 (75\%) komplikacje pooperacyjne obejmowały: płynotok (2), obrzęk mózgu (1), zakrzepicę żylną mózgu (1), krwawienie do loży pooperacyjnej (1) oraz ogniskowe deficyty neurologiczne wskutek manipulacji (3). W większości przypadków (5) stwierdzono oponiaki o niskim stopniu złośliwości histologicznej (I stopień wg WHO), które jednak wykazywały szczególne cechy histopatologiczne: ogniskowy wzrost zagęszczenia komórkowego i podwyższony indeks proliferacyjny, pleomorfizm jąder komórkowych, pojedyncze figury podziałów mitotycznych oraz, w jednym

Correspondence address: Przemysław Kunert, Katedra i Klinika Neurochirurgii, Warszawski Uniwersytet Medyczny, ul. Banacha 1A, 02-097 Warszawa, fax: + 48226583653 , e-mail: pkunert@wp.pl

Received: 6.02.2012; accepted: 13.06.2012 
Conclusions: Radiation-induced tumours of the meninges show certain characteristic histopathological features, which may promote invasiveness of the tumour and higher risk of malignancy.

Key words: radiation-induced tumour, meningioma, fibrosarcoma, radiotherapy.

\section{Introduction}

Wilhelm Roentgen discovered X-rays in 1895 and shortly thereafter its usage in cancer patients was documented [1]. In the $20^{\text {th }}$ century, rapid development of radiation treatment methods brought awareness of its side effects. Maria Skłodowska-Curie helped to introduce the use of radiation in medicine; nevertheless, she died almost certainly of radiation-induced leukaemia. The first experimental reports of the possible carcinogenic effects of ionising radiation appeared in the second decade of the $20^{\text {th }}$ century, and the first radiationinduced sarcomas in humans were documented in the early 1920s [2].

Today, radiotherapy is commonly used. Moreover, exposure to $\mathrm{X}$-rays is increasing due to progress in interventional radiology as well as the widespread use of computed tomography (CT). About 60 million CT examinations were performed in the United States in 2005, which is three times more than 10 years earlier. Theoretical calculations indicate that as many as $1.5-2 \%$ of neoplasms could be caused by radiation doses during CT examination [3].

Among brain tumours, which are believed to be caused by irradiation, the most frequent are meningiomas, gliomas and sarcomas [4]. Radiation-induced meningiomas (RIMs) have usually been reported as a later consequence of prior low- or high-dose radiotherapy. In the present study, we attempted to determine the distinct features of radiation-induced tumours of meninges with an emphasis on clinical and histopathological aspects. The study group consisted of seven RIMs and one fibrosarcoma arising from meninges. We decided to include the last case in the study because it represents the same clinical problem and aetiopathogenesis. przypadku, cechy naciekania mózgu. W jednym przypadku rozpoznano oponiaka II stopnia wg WHO, w jednym III stopnia wg WHO i w jednym włókniakomięsaka opon. Przeżycie wolne od zdarzeń i przeżycie całkowite w okresie obserwacji trwającym 4,4 roku wyniosły odpowiednio $63 \%$ i $75 \%$.

Wnioski: Popromienne guzy opon mózgowo-rdzeniowych wykazują znamienne cechy histopatologiczne, które mogą sprzyjać większej inwazyjności i złośliwości tych guzów.

Słowa kluczowe: guz popromienny, oponiak, włókniakomięsak, radioterapia.

\section{Material and methods}

The personal files of 433 patients operated on for intracranial meningeal tumours between 2000 and 2008 have been retrospectively reviewed. Eight patients (2\%) developed tumours that met the criteria of radiationinduced neoplasms. These tumours were qualified as postradiation ones according to the adapted Cahan's criteria: the tumour had to arise at least several years after irradiation within the irradiated area and had to be histologically distinct from the previously treated tumour [2]. Among these 8 patients, there were 4 women and 4 men, aged between 28 and 67 (mean, 43). The patient's age at radiotherapy ranged from 2 to 31 years (mean, 19). The post-radiation tumours were diagnosed from 7 to 36 years after radiation treatment (mean, 24). Prior radiotherapy was applied to head (7) or neck neoplasms (1) including orbit rhabdomyosarcoma (2), hypophyseal adenoma (1), medulloblastoma (1), oligodendroglioma (1), anaplastic astrocytoma (1), unverified pineal region tumour (1), and thyroid neoplasm (1). The patient after thyroid gland irradiation had two tumours: foramen magnum meningioma and acoustic schwannoma. Cranial base location suggested a possible relationship between these tumours and previously administered radiation therapy.

In all cases, high-dose irradiation was used: $\mathrm{X}$-ray radiotherapy in 3 and Co-60 radiotherapy in 5 patients. All the patients had solitary post-radiation meningeal tumours, but two of them had other coexisting neoplasms in the irradiated area (vestibular schwannoma - 1, basocellular carcinoma - 1; see Fig. 1F, H, I).

Each intraoperative difficulty and postoperative complication was analysed as possibly related to post-radiation changes. Early results were evaluated according to the Glasgow Outcome Scale (GOS) and the long-term 


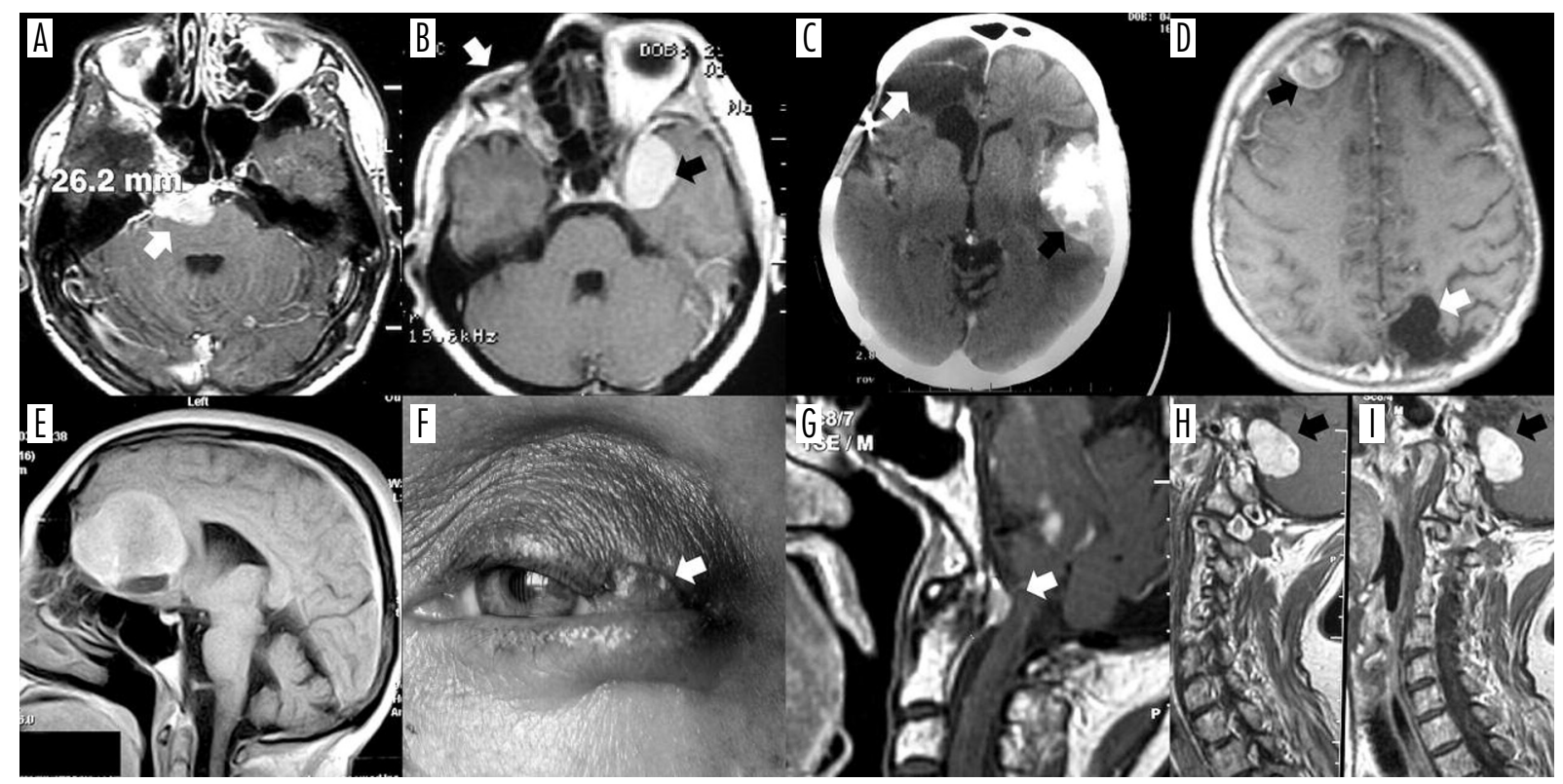

Fig. 1. A) Magnetic resonance imaging (MRI) scan demonstrating progression of the petrous apex radiation-induced meningioma (RIM) 19 months after initial surgery in patient K.G., who had undergone radiotherapy for rhabdomyosarcoma of the right orbit. B) Patient E.A. Axial MRI scan shows medial sphenoid wing RIM (black arrow) that developed 29 years after surgery and radiotherapy for rhabdomyosarcoma (white arrow). C) Patient D.S. CT scan shows left temporal convexity RIM (black arrow) 36 years after surgery and radiotherapy for pituitary adenoma. Changes after surgery for pituitary adenoma are visible in the right frontal lobe (white arrow). D) Patient W.A. Axial MRI scan demonstrating convexity RIM (black arrow) 17 years after surgery and radiotherapy for anaplastic astrocytoma (white arrow). E\&F) Patient S.E. E) Sagittal MRI scan shows olfactory groove RIM, 27 years after radiotherapy for pineal gland tumour. F) Basal cell carcinoma on the eyelid in the irradiated area (white arrow) that developed 6 year after resection of RIM. G-I) Patient B.E. Sagittal MRI scans show anterior foramen magnum meningioma (white arrow) and vestibular schwannoma (black arrows) 36 years after radiotherapy for thyroid neoplasm

results according to the Karnofsky Performance Scale (KPS). Based on ambulatory records and telephone surveys, reliable follow-up data were obtained in all patients. Postoperative follow-up ranged from 10 months to 9 years (mean, 4.4 years). In the group of 7 patients with meningiomas, follow-up ranged from 2.5 to 9 years (mean, 4.9). Demographic data, previous treatment, presenting symptoms and tumour location are detailed in Table 1 and in Figures 1 and 2.

Histological studies were performed on eight secondary radiation-induced meningeal tumours including 7 cases of meningiomas and 1 case of fibrosarcoma. The formalin-fixed, paraffin-embedded biopsy specimens were routinely stained with haematoxylin-eosin $(\mathrm{H} \& \mathrm{E})$ and silver impregnation for reticulin. Immunohistochemical analysis was performed on selected paraffin-embedded specimens according to the labelled streptavidin-biotin complex method (ABC) with $\mathrm{DAB}$ as chromogen, using antibodies against epithelial membrane antigen (EMA), vimentin and S-100 protein (all antibodies from Dako). The proliferation index was evaluated using antibody against MIB-1 antigen (monoclonal antibody, clone MIB-1, 1:100; Dako).

\section{Results}

\section{Surgical treatment}

All secondary tumours were removed microsurgically. In the patient with post-radiation foramen magnum meningioma and vestibular schwannoma, both tumours were resected during the same procedure. Removal of the complete tumour with dural attachment was achieved in 4 cases (Simpson grade I). In three patients, the tumour was removed followed by coagulation of the dural attachment (Simpson grade II). In the case of petrous apex meningioma infiltrating cavernous sinus, a subtotal excision was performed (Simpson grade IV). This patient was reoperated on because of rapid tumour progression toward the middle and the posterior cranial fossa 1.5 years later. During the second procedure, Simpson grade II resection was achieved and thereafter stereotactic irradiation was given.

Simpson grade II resection was carried out in the patient with meningeal fibrosarcoma. Afterwards, the patient was referred to an oncologist but was not qualified for supplementary irradiation due to the prior use of a maximum dose of irradiation. 


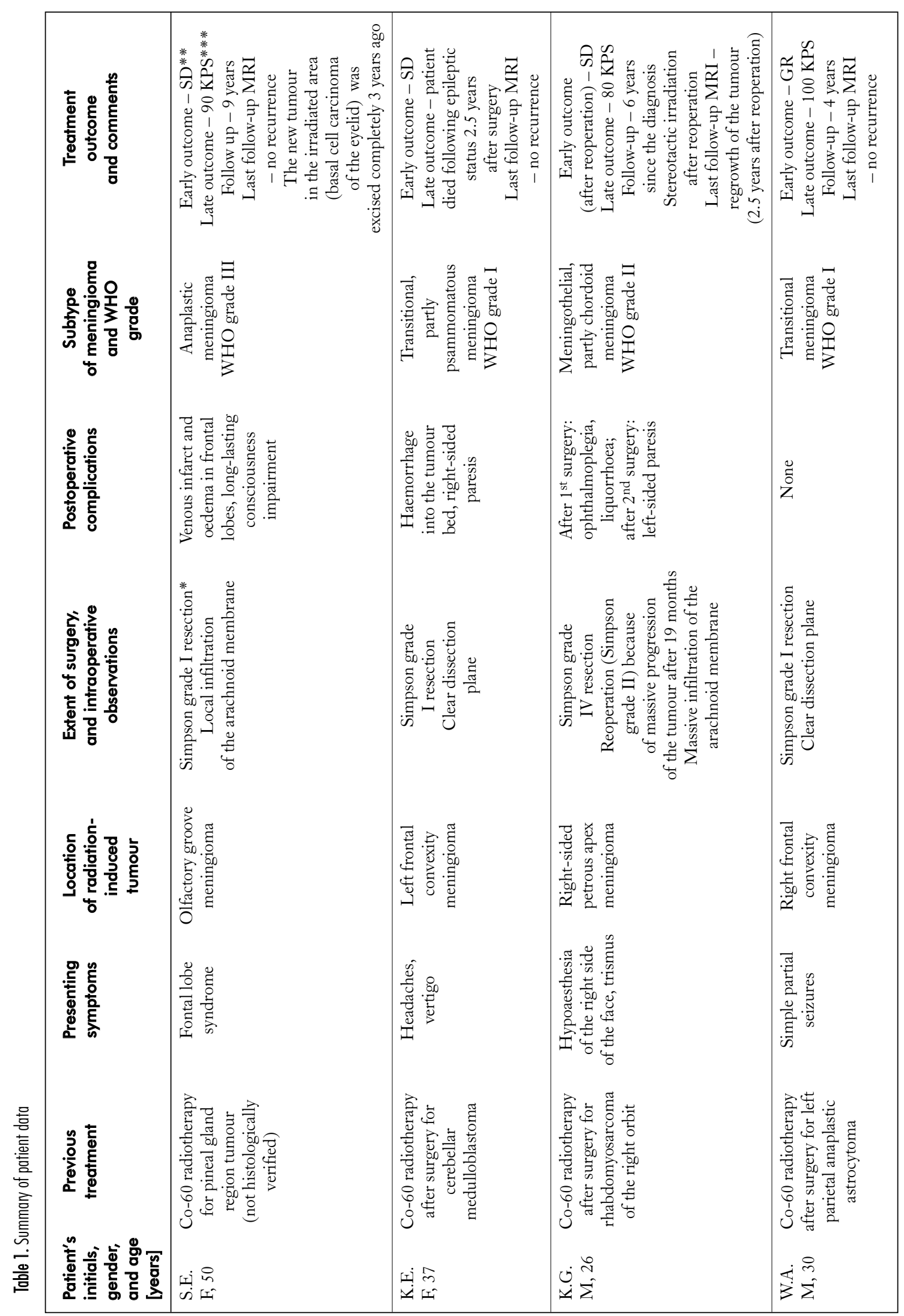




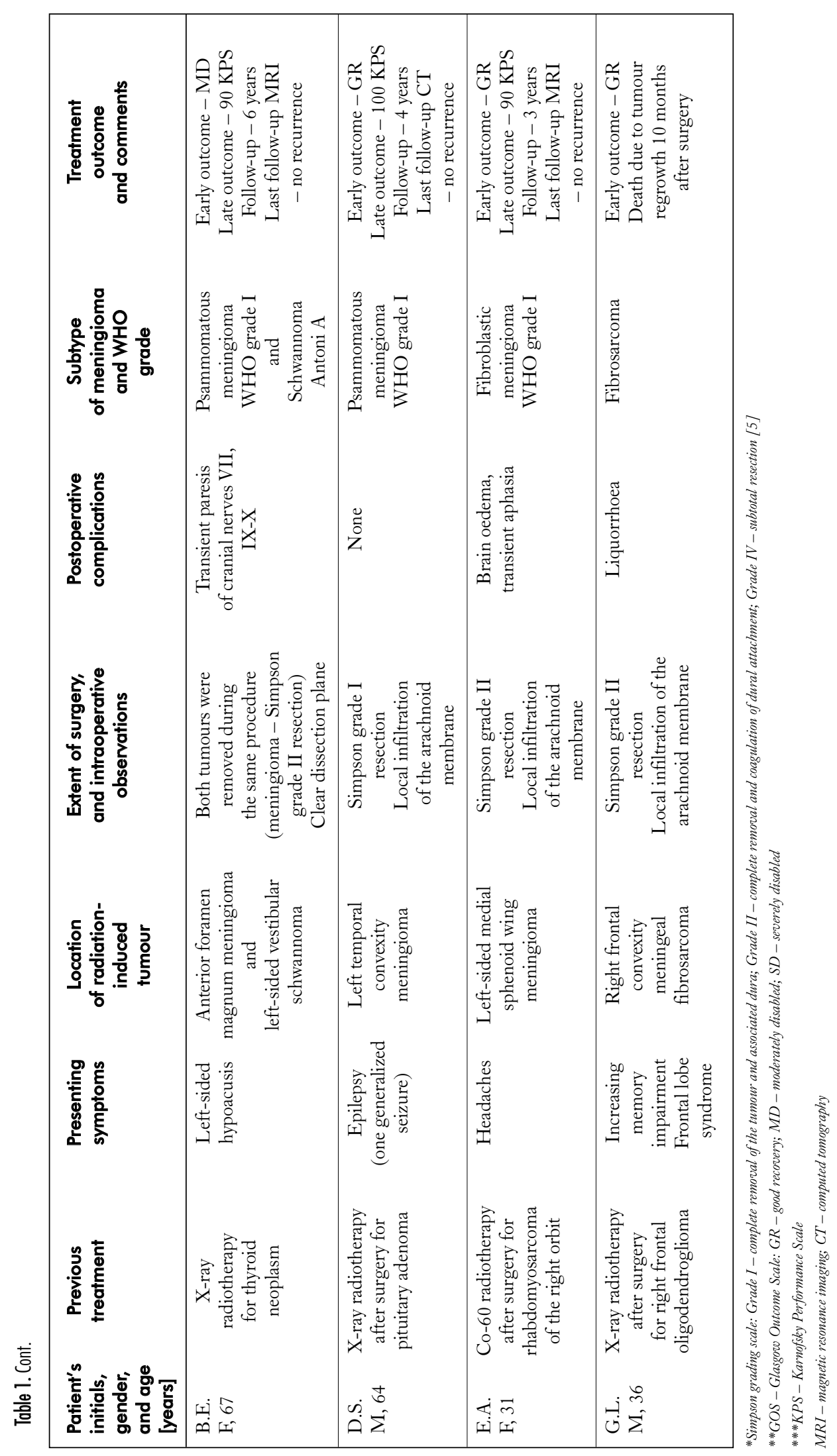




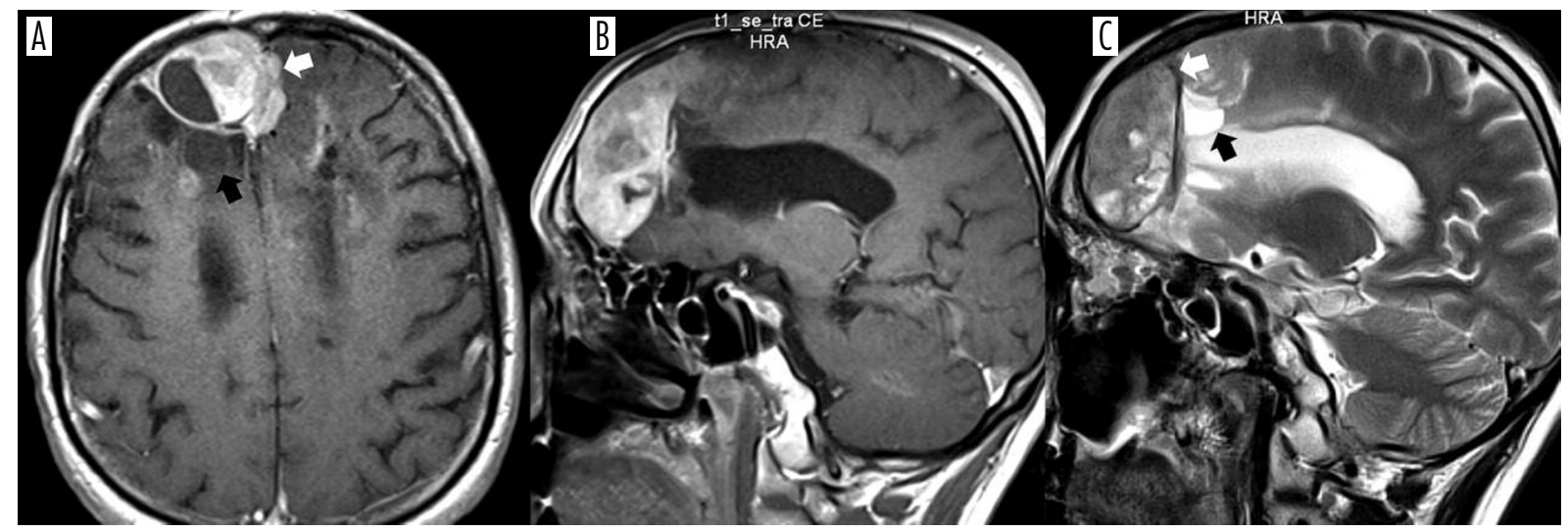

Fig. 2. A-C) Patient G.L. with meningeal fibrosarcoma 12 years after surgery and 7 years after radiotherapy for right frontal oligodendroglioma. White arrow - postradiation tumour. Black arrow - compressed tumour bed after primary tumour removal

A clear dissection plane between the tumour and arachnoid was encountered in three cases. Local thickening of arachnoid membrane and tumoural infiltration of the arachnoid hindering dissection were noted intraoperatively in 4 of 8 patients. Massive infiltration of the arachnoid membrane was present in one patient with petrous apex meningioma.

\section{Postoperative complications}

The postoperative course was uneventful in two patients only. Both patients were discharged home in good condition (good recovery according to GOS; see Table 1). In the remaining $6(75 \%)$ cases the postoperative course was complicated. The complications included liquorrhoea (2), long-lasting consciousness deterioration due to venous thrombosis (1), deep hemiparesis due to bleeding into the tumour bed (1), aphasia due to brain oedema (1), deep hemiparesis after resection of the petrous apex meningioma infiltrating the brain stem peduncle (1), paresis of the lower cranial nerves (1) and ophthalmoplegia due to manipulation (1). A complicated postoperative course was noted after each procedure in the patient who was operated on twice for petrous apex meningioma. The outcomes in these patients at the time of discharge, based on GOS scores, were as follows: good recovery -2 patients; moderately disabled -1 patient; severely disabled -3 patients.

\section{Histopathology of radiation-induced tumours}

Most radiation-induced meningiomas ( 5 cases) were benign, including various histological subtypes: transitional ( 1 case), combined transitional/psammomatous (1 case), fibroblastic (1 case) and psammomatous (2 ca- ses), all corresponding to WHO grade I. The transitional meningioma showed typical whorls of neoplastic cells accompanied by the presence of numerous collagenised vessels. In the transitional/psammomatous case, focal infiltration along the fibres of the dura mater was documented (Fig. 3A). The fibroblastic meningioma consisted of fusiform, spindle cells accompanied by an abundance of intercellular collagen deposition and advanced focal fibrosis. Two psammomatous meningiomas exhibited numerous psammoma bodies and one of them was heavily mineralised with masses of calcifications. In these secondary benign meningiomas of various histological patterns, the focal increase of cellularity, pleomorphism of nuclei and a few mitotic figures could be seen (Fig. 3B). The studies on proliferative activity of meningothelial cells showed a relatively low MIB-1 labelling index, but its focal increase was encountered. It was possible to evaluate the microscopic evidence of brain invasion in one case of psammomatous meningioma only. The neoplastic tissue displayed adherence to the pia with focal invasion of its surface and infiltration of the underlying brain parenchyma with reactive astrogliosis (Fig. 3C).

Two cases of secondary meningiomas corresponded to a higher grade of malignancy. One case was diagnosed as meningioma WHO grade II. This tumour displayed heterogeneous morphology with two different histological patterns: one consisted of meningotheliomatous areas and the other displayed chordoid components with typical ribbons of epithelioid cells (Fig. 3D). Only one case of radiation-induced meningiomas was diagnosed as anaplastic meningioma, WHO grade III. This meningioma revealed histological features of malignancy including cytological atypia, necrosis, marked mitotic activity and high MIB-1 labelling index (Fig. 3E). 

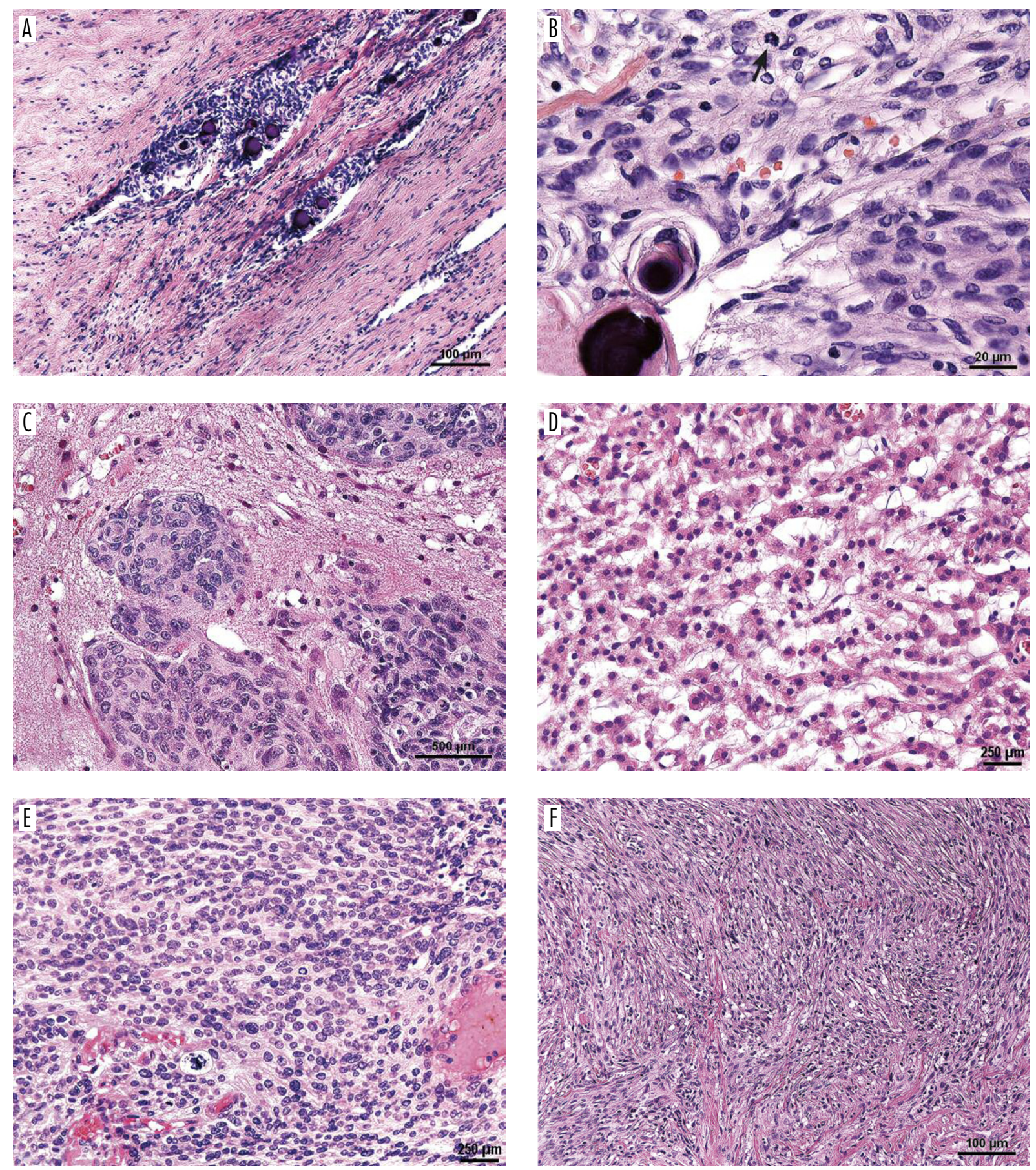

Fig. 3. A) Intradural spread of benign transitional/psammomatous meningioma. Bar - $100 \mu \mathrm{m}$. B) Mitotic figure (arrow) in psammomatous meningioma. Bar $-20 \mu \mathrm{m}$. C) Brain invasion of meningioma with cohesive tongues of neoplastic tissue extending into the underlying cortex. Bar $-500 \mu \mathrm{m}$. D) Chordoid area in atypical meningioma. Bar $-250 \mu \mathrm{m}$. E) Anaplastic meningioma with numerous mitotic figures. Bar $-250 \mu \mathrm{m}$. F) Fibrosarcoma with interlacing bundles of fibroblastic cells. Bar $-100 \mu \mathrm{m}$.

One case of meningeal tumour was recognised as a high grade sarcoma. The compact interlacing bundles of spindle cells were arranged in a fascicular 'herringbone' pattern typical for fibrosarcoma (Fig. 3F). The tu - mour was mitotically active and exhibited an abundance of pericellular reticulin fibres. Immunohistochemically, the neoplastic cells were positive for vimentin but negative for EMA and S-100 protein. The tumour extend- 
ed diffusely into the brain tissue along perivascular spaces.

The mean latency period for meningiomas was 27 years, and for fibrosarcoma was 7 years. The mean latency period for meningiomas in patients irradiated before their $20^{\text {th }}$ birthday was 21 years and in older patients 33 years.

\section{Follow-up}

Two patients died in the follow-up period. One patient died of massive fibrosarcoma regrowth without distant metastases 10 months after surgery. The other patient died following status epilepticus and persistent vegetative status 2.5 years after surgery for benign meningioma. The last MRI examination performed 2 years after surgery revealed no signs of tumour recurrence.

In the six survivors, follow-up ranged from 3 to 9 years (mean, 5.3) and in all patients the KPS scores were satisfactory ( $80-1$ patient; $90-3$ patients; $100-$ 2 patients). In three of them, significant withdrawal of the neurological deficit was observed. At the last follow-up imaging examinations, 5 of 6 survivors had no regrowth. In the patient who was operated on twice and irradiated for petrous apex meningioma (WHO grade II), the follow-up MRI taken 2.5 years after reoperation revealed regrowth of the tumour.

One patient developed basal cell carcinoma of the eyelid in the irradiated area 31 years after irradiation and 4 years after secondary meningioma resection (Fig. 1F). The new tumour was successfully removed and the patient fully recovered. Now, 9 years after resection of anaplastic meningioma, she is stable without tumour recurrence.

\section{Discussion}

Carcinogenesis can be a rare and delayed side effect of radiotherapy. RIMs are thought to be caused mostly by high-dose radiotherapy [6-10]. However, low-dose irradiation used in the past for tinea capitis or even doses of 1-2 Gy are proven risk factors [11-14]. The risk of meningioma in irradiated subjects is 6-10 times higher than in non-irradiated ones [12]. The assessment of actual epidemiology of RIMs is difficult for many reasons. The problem is not only associated with the use of radiation treatment. It must be remembered that patients are also put at risk by the diagnostic use of X-rays. Dental X-ray machines used in the past delivered a dose of 1-3 Gy to the skin per session. It has been documented that such serial full-mouth X-rays increased the risk of meningioma [15]. Nowadays, the potential risk is associated primarily with the development and widespread use of CT and also interventional radiology techniques (e.g. multiple therapeutic and follow-up angiography sessions) $[16,17]$. Radiological examinations in many cases seem to be misused [18]. Therefore, the incidence of RIMs will probably continue to grow in the future $[4,8]$. Brenner estimates that approximately 65 million adult and 5 million paediatric CT studies are carried out per year in the USA and about 1/3 of them are unnecessary or could be replaced by other methods [19].

\section{Clinical considerations}

As compared to spontaneous meningiomas, our limited series confirmed the well-known characteristics of RIMs: younger age and no marked female preponderance [6]. Similarly to other series [9,20,21], RIMs were diagnosed after a mean latency period exceeding 20 years. The mean latency period for meningiomas was 27 years, and for meningeal fibrosarcoma was 7 years. Our data seem to confirm that the shorter latency period may be related to younger age at irradiation (see Table 2) $[6,10]$.

Post-radiation tumours of meninges exhibit a more malignant nature than spontaneous meningiomas $[6,8$, 21]. In the series of Al-Mefty et al. [20] post-radiation meningiomas of WHO grade > I were found in $38 \%$, and the recurrence rate was $100 \%$. In our series, three (38\%) tumours were in WHO grade $>\mathrm{I}$, and recurrence was observed in $25 \%$ during a mean follow-up of 4.4 years. However, satisfactory long-term outcome without tumour recurrence was noted in $5(63 \%)$ patients only.

Multiple occurrence of RIMs is often reported $[6,8,9,20,22]$ but this was not confirmed in the present series. Nonetheless, in two (25\%) patients, other secondary tumours coexisted in the irradiated area: schwannoma and basal cell carcinoma. Schwannomas are rarely reported as radiation-induced [23], while basal cell carcinomas are known as the most frequent post-radiation scalp tumours [24]. These observations lead to the conclusion that patients following head irradiation are at risk of various secondary neoplasms, which may arise in different time periods. Therefore, these patients need long-term surveillance even after the successful treatment of RIM. 
Table 2. Patient's age at radiotherapy, latency period and tumour grade

\begin{tabular}{|c|c|c|c|c|}
\hline $\begin{array}{l}\text { Patient's } \\
\text { initials } \\
\text { and age } \\
\text { at radiotherapy } \\
\text { [years] }\end{array}$ & & $\begin{array}{l}\text { Latency } \\
\text { [years] }\end{array}$ & $\begin{array}{c}\text { Age at } \\
\text { presentation } \\
\text { of post-radiation } \\
\text { tumour [years] }\end{array}$ & $\begin{array}{l}\text { Post-radiation tumour, } \\
\text { WHO classification }\end{array}$ \\
\hline E.A., 2 & 29 & \multirow{4}{*}{$\begin{array}{c}\text { mean latency of } \\
22 \text { years if radiotherapy } \\
\text { at age }<20\end{array}$} & 31 & Meningioma, WHO grade I \\
\hline K.G., 6 & 20 & & 26 & Meningioma, WHO grade II \\
\hline W.A., 13 & 17 & & 30 & Meningioma, WHO grade I \\
\hline K.E., 17 & 20 & & 37 & Meningioma, WHO grade I \\
\hline S.E., 23 & 27 & \multirow{3}{*}{$\begin{array}{c}\text { mean latency of } 33 \text { years } \\
\text { if radiotherapy } \\
\text { at age }>20\end{array}$} & 50 & Meningioma, WHO grade III \\
\hline D.S., 28 & 36 & & 64 & Meningioma, WHO grade I \\
\hline B.E., 31 & 36 & & 67 & Meningioma, WHO grade I \\
\hline G.L., 29 & 7 & & 36 & Fibrosarcoma \\
\hline
\end{tabular}

Cahan's criteria for diagnosis of radiation-induced tumour were developed in 1948 and since that time there have been many remarks on them $[2,25]$. The time criterion is worth mentioning, because there were many reports on secondary tumours that appeared earlier than 5 years after radiotherapy. This group also includes meningiomas [26]. Therefore, the revised criteria, developed by Murray et al. [25], do not comprise a time interval condition. The criterion that the secondary tumour must arise in the irradiated field needs special consideration. In the light of the recent research of Claus et al. [27] the risk of meningioma is significantly elevated in patients who underwent radiation therapy for thyroid cancer. This suggests that regions in the vicinity of the directly irradiated field are also at risk.

\section{Postoperative complications}

In this small series, the risk of various postoperative complications was $75 \%$ per patient and $78 \%$ per procedure. In contrast, the overall rate of postoperative complications in surgery of incidental convexity meningiomas is currently about $10 \%[28,29]$. Not all complications are related to post-radiation changes. Four of 8 tumours were located in the cranial base. At least transient cranial nerve paresis occurs relatively often in that location. We had two such cases. In one case, transient paresis of the lower cranial nerves occurred after removal of two cranial base tumours during the same surgery. In the other case, ophthalmoplegia appeared after partial removal of petrous apex meningioma invading the cavernous sinus. In this case, there was no clear tumourbrain interface. On the other hand, in our opinion, the thickening of the arachnoid, as was seen in this case, is often found in areas previously irradiated. It could be a possible cause of difficulties in finding the correct dissection plane [30]. The question arises whether thickening of the arachnoid membrane is a manifestation of post-radiation changes or is a response to more aggressive tumour behaviour. Significant thickening and adhesions of the arachnoid were identified in five cases and in two of them symptomatic brain oedema occurred postoperatively. In cases of benign meningiomas, thickening and adhesions were found in 2 of 5 cases. Among the more aggressive tumours (WHO grade $>$ I and fibrosarcoma), thickening of the arachnoid and at least local subpial infiltration were noted in all three cases. Our series is not large, so we cannot reach a conclusion; nonetheless both mechanisms may play some role. Alvernia et al. [31] noted that the problems with finding the safe dissection plane during meningioma resection are not always related to the higher tumour grade [31].

The other reported complications such as liquorrhoea or bleeding into the surgical bed can occur after any brain surgery, but radiation-induced damage of skin and connective tissues could also promote them [32].

\section{Histopathological considerations}

The majority of radiation-induced tumours in our series appeared to be benign meningiomas of various types, assigned as WHO grade I. This is in agreement with other reports documenting that RIMs of benign morphology are the most frequent types in the adult population [20,22]. Most RIMs revealed features similar to spontaneous benign meningiomas; some peculiar 
histopathological characteristics could be identified, however, including areas of hypercellularity, single mitoses or focal increase of MIB-1 labelling index. However, these features were insufficient to fulfil criteria for the diagnosis of higher grade meningiomas. These features might also be encountered in common classical meningiomas of corresponding subtypes; thus, the earlier suggestion that radiation-associated cerebral meningiomas can be defined as 'a separate nosological subgroup' [33] seems to be not sufficiently supported. It ought to be mentioned, however, that most RIMs despite their low grade histology might exhibit a tendency towards more aggressive biological behaviour compared with sporadic cases.

Meningiomas of higher grade (II and III) were established in two cases and represented about 38\% of all reported cases, which is similar to data published elsewhere [20].

A second neoplasm other than meningioma was encountered in one case and diagnosed as fibrosarcoma with typical histopathology $[34,35]$. The meningeal fibrosarcoma described by us mimicked meningioma in imaging studies. Fibrosarcoma is an extremely rare intracranial tumour. In the series of Paulus et al. [34] of 25,000 brain tumour biopsies, this type of neoplasm was diagnosed in one case only.

Fibrosarcoma arises in the meninges from meningothelial cells [36] and is usually linked with poor prognosis because of the high risk of local relapse and systemic metastases even after aggressive multimodal treatment [35,37-40]. According to the literature, the survival time is usually shorter than one year [35]. Despite its rarity, the occurrence of these tumours in previously irradiated patients is well known. The latency period is, as a rule, much shorter than for post-radiation meningiomas [36,37]. Aydin et al. [41] described a case of rapidly growing supratentorial fibrosarcoma as short as 15 months after treatment of medulloblastoma. In the case described by us, the latency period was seven years and was almost four times shorter than for meningiomas. The optimal treatment of fibrosarcoma is complete surgical removal followed by radiotherapy and, optionally, chemotherapy [42]. However, multimodal treatment is usually hampered in radiationinduced tumours because radiotherapy options have been exhausted before. The fibrosarcoma in our patient had arisen from the dura covering the tumour bed after a previously treated glioma (Fig. 2). The primary tu mour was oligodendroglioma (WHO grade II). Okeda et al. [36] gave attention to two cases of fibrosarcoma which grew out of the site of a previously irradiated high grade glioma. However, in both cases the sarcoma appeared very quickly, i.e. within one year following irradiation, and adhered to the re-growing glioblastoma.

\section{Conclusions}

1. Radiation-induced tumours of the meninges show certain characteristic histopathological features, which may promote invasiveness of the tumour and higher risk of malignancy.

2. It seems that the surgery for postradiation meningiomas may be associated with a higher risk of postoperative complications.

\section{Disclosure}

Authors report no conflict of interest.

\section{References}

1. Chang S.D., Adler J.R., Steinberg G.K. General and historical considerations of radiotherapy and radiosurgery. In: Winn H.R. [ed.]. Youmans Neurological Surgery. $5^{\text {th }}$ edition. Saunders, Philadelphia 2004, pp. 3991-3998.

2. Cahan W.G., Woodard H.Q., Higinbotham N.L., et al. Sarcoma arising in irradiated bone: report of 11 cases. Cancer 1948; 1: 3-29.

3. Brenner D.J., Hall E.J. Computed tomography - an increasing source of radiation exposure. N Engl J Med 2007; 357: 22772284.

4. Kleinschmidt-Demasters B.K., Kang J.S., Lillehei K.O. The burden of radiation-induced central nervous system tumors: a single institution s experience. J Neuropathol Exp Neurol 2006; 65: 204-216.

5. Simpson D. The recurrence of intracranial meningiomas after surgical treatment. J Neurol Neurosurg Psychiatry 1957; 20: 22-39.

6. Strojan P., Popovic M., Jereb B. Secondary intracranial meningiomas after high-dose cranial irradiation: report of five cases and review of the literature. Int J Radiat Oncol Biol Phys 2000; 48: 65-73.

7. Matyja E., Kroh H., Bojarski P. Intracranial meningiomas following irradiation therapy for brain tumors. Folia Neuropathol 1994; 32: 253-254.

8. Musa B.S., Pople I.K., Cummins B.H. Intracranial meningiomas following irradiation - a growing problem? BrJ Neurosurg 1995; 9: 629-637.

9. Banerjee J., Päk̈kkö E., Harila M., et al. Radiation-induced meningiomas: a shadow in the success story of childhood leukemia. Neuro Oncol 2009; 11: 543-549.

10. Caroli E., Salvati M., Roperto R., et al. High-dose radiationinduced meningioma in children - case report and critical review of the literature. Zentralbl Neurochir 2005; 66: 39-42. 
11. Longstreth W.T. Jr., Dennis L.K., McGuire V.M., et al. Epidemiology of intracranial meningioma. Cancer 1993; 72: 639-648

12. Wiemels J., Wrensch M., Claus E.B. Epidemiology and etiology of meningioma. J Neurooncol 2010; 99: 307-314.

13. Umansky F., Shoshan Y., Rosenthal G., et al. Radiation-induced meningioma. Neurosurg Focus 2008; 24: E7.

14. Sadetzki S., Flint-Richter P., Ben-Tal T., et al. Radiation-induced meningioma: a descriptive study of 253 cases. J Neurosurg 2002; 97: 1078-1082.

15. Longstreth W.T., Phillips L.E., Drangsholt M., et al. Dental $\mathrm{X}$-rays and the risk of intracranial meningioma: a populationbased case-control study. Cancer 2004; 100: 1026-1034.

16. Griffey R.T., Sodickson A. Cumulative radiation exposure and cancer risk estimates in emergency department patients undergoing repeat or multiple CT. AJR Am J Roentgenol 2009; 192: 887-892.

17. Sodickson A., Baeyens P.F., Andriole K.P., et al. Recurrent CT, cumulative radiation exposure, and associated radiation-induced cancer risks from CT of adults. Radiology 2009; 251: 175-184.

18. Kaups K.L., Davis J.W., Parks S.N. Routinely repeated computed tomography after blunt head trauma: does it benefit patients? J Trauma 2004; 56: 475-480.

19. Brenner D.J. Should we be concerned about the rapid increase in CT usage? Rev Environ Health 2010; 25: 63-68.

20. Al-Mefty O., Topsakal C., Pravdenkova S., et al. Radiationinduced meningiomas: clinical, pathological, cytokinetic, and cytogenetic characteristics. $J$ Neurosurg 2004; 100: 1002-1013.

21. Galloway T.J, Indelicato D.J, Amdur R.J., et al. Favorable outcomes of pediatric patients treated with radiotherapy to the central nervous system who develop radiation-induced meningiomas. Int J Radiat Oncol Biol Phys 2011; 79: 117-120.

22. Lillehei K.O., Donson A.M., Kleinschmidt-DeMasters B.K. Radiation-induced meningiomas: clinical, cytogenetic, and microarray features. Acta Neuropathol 2008; 116: 289-301.

23. Salvati M., Polli F.M., Caroli E., et al. Radiation-induced schwannomas of the nervous system. Report of five cases and review of the literature. J Neurosurg Sci 2003; 47: 113-116.

24. Mseddi M., Dammak A., Jellouli M., et al. Profile of basal cell carcinomas of the scalp after radiotherapy for tinea capitis (about 63 cases). Rev Med Liege 2006; 61: 724-727.

25. Murray E.M., Werner D., Greeff E.A., et al. Postradiation sarcomas: 20 cases and a literature review. Int J Radiat Oncol Biol Phys 1999; 45: 951-961.

26. Choudhary A., Pradhan S., Huda M.F., et al. Radiation induced meningioma with a short latent period following high dose cranial irradiation - case report and literature review. $J$ Neurooncol 2006; 77: 73-77.

27. Claus E.B., Calvocoressi L., Bondy M.L., et al. Family and personal medical history and risk of meningioma. Clinical article. J Neurosurg 2011; 115: 1072-1077.

28. Morokoff A.P., Zauberman J., Black P.M. Surgery for convexity meningiomas. Neurosurgery 2008; 63: 427-433.

29. Sanai N., Sughrue M.E., Shangari G., et al. Risk profile associated with convexity meningioma resection in the modern neurosurgical era. J Neurosurg 2010; 112: 913-919.
30. Kunert P., Matyja E., Janowski M., et al. Rapid growth of small, asymptomatic meningioma following radiosurgery. $\mathrm{Br} J$ Neurosurg 2009; 23: 206-208.

31. Alvernia J.E., Dang N.D., Sindou M.P. Convexity meningiomas: study of recurrence factors with special emphasis on the cleavage plane in a series of 100 consecutive patients. J Neurosurg 2011; 115: 491-498.

32. Gu Q., Wang D., Cui C., et al. Effects of radiation on wound healing. J Environ Pathol Toxicol Oncol 1998; 17: 117-123.

33. Rubinstein A.B., Shalit M.N., Cohen M.L., et al. Radiationinduced cerebral meningioma: a recognizable entity. $J$ Neurosurg 1984; 61: 966-971.

34. Paulus W., Slowik F., Jellinger K. Primary intracranial sarcomas: histopathological features of 19 cases. Histopathology 1991; 18: 395-402.

35. Gaspar L.E., Mackenzie I.R., Gilbert J.J., et al. Primary cerebral fibrosarcomas. Clinicopathologic study and review of the literature. Cancer 1993; 72: 3277-3281.

36. Okeda R., Mochizuki T., Terao E., et al. The origin of intracranial fibrosarcoma. Acta Neuropathol (Berl) 1980; 52: 223-230.

37. Yamamoto A., Hashimoto N., Yamashita J., et al. A case of radiation-induced intracranial fibrosarcoma with repeated episodes of intratumoral hemorrhage. No Shinkei Geka 1989; 17: 193-196.

38. Lopes M.B., Lanzino G., Cloft H.J., et al. Primary fibrosarcoma of the sella unrelated to previous radiation therapy. Mod Pathol 1998; 11: 579-584.

39. Aung T.H., Tse C.H. Bifrontal meningeal fibrosarcoma in a patient with metastases to the liver, kidneys and suprarenal glands. Aust N Z J Surg 1993; 63: 746-748.

40. Khan W.A., Attal H., Vernick J., et al. Cytodiagnosis of a meningeal fibrosarcoma metastatic to the thyroid gland. Semin Diagn Pathol 2001; 18: 104-109.

41. Aydin F., Ghatak N.R., Leshner R.T. Possible radiation-induced dural fibrosarcoma with an unusually short latent period: case report. Neurosurgery 1995; 36: 591-594.

42. Bisogno G., Roganovic J., Carli M., et al. Primary intracranial fibrosarcoma. Childs Nerv Syst 2002; 18: 648-651. 